\title{
History of insecticide resistance of Triatominae vectors
}

\author{
Grasielle Caldas DÁvila Pessoa ${ }^{[1]}$, Pedro Albajar Vinãs ${ }^{[2]}$, \\ Aline Cristine Luiz Rosa ${ }^{[1]}$ and Liléia Diotaiuti ${ }^{[1]}$
}

[1]. Laboratório de Referência em Triatomíneos e Epidemiologia da Doença de Chagas, Centro de Pesquisas René Rachou, Fundação Oswaldo Cruz, Belo Horizonte, Minas Gerais, Brasil. [2]. Organização Mundial de Saúde, Genebra, Suiça.

\begin{abstract}
In the last 15 years, different types of Triatominae resistance to different insecticides have been reported; thus, resistance may be more widespread than known, requiring better characterization and delimitation, which was the aim of this review. This review was structured on a literature search of all articles from 1970 to 2015 in the PubMed database that contained the keywords Insecticide resistance and Triatominae. Out of 295 articles screened by title, 33 texts were selected for detailed analysis. Insecticide resistance of Triatomines is a complex phenomenon that has been primarily reported in Argentina and Bolivia, and is caused by different factors (associated or isolated). Insecticide resistance of Triatominae is a characteristic inherited in an autosomal and semi-dominant manner, and is polygenic, being present in both domestic and sylvatic populations. The toxicological profile observed in eggs cannot be transposed to different stages of evolution. Different toxicological profiles exist at macro- and microgeographical levels. The insecticide phenotype has both reproductive and developmental costs. Different physiological mechanisms are involved in resistance. Studies of Triatomine resistance to insecticides highlight three deficiencies in interpreting the obtained results: I) the vast diversity of methodologies, despite the existence of a single guiding protocol; II) the lack of information on the actual impact of resistance ratios in the field; and III) the concept of the susceptibility reference lineage. Research on the biological and behavioral characteristics of each Triatominae species that has evolved resistance is required in relation to the environmental conditions of each region.
\end{abstract}

Keywords: Insecticide resistance. Triatominae. Chagas disease.

\section{INTRODUCTION}

For over a century since its discovery, Chagas disease (CD), or American trypanosomiasis, remains a serious public health problem, and represents the main cause of cardiac lesions in young and adult people economically productive ${ }^{(1)}$. Chagas disease, caused by Trypanosoma cruzi Chagas 1909, affects about 6-7 million people, mostly in Latin America ${ }^{(2)}$. The geographical distribution of human Chagasic infection, including wild reservoirs and vectors are primarily found in the Americas, roughly from $46^{\circ} \mathrm{N}$ to $46^{\circ} \mathrm{S}$, except for species of the genera Linchosteus and Rubrofasciata complex. The genera Linshcosteus is found only in the Indian subcontinent and, Triatoma rubrofasciata is recorded from port areas throughout the tropics and subtropics, and a small group of seven related species of Triatoma are recorded from eastern Asia. The primary form of transmission of CD $(\sim 70 \%)$ in most Latin American areas remains vectorial, being dependent on this form

Corresponding author: Dra. Liléia Diotaiuti. Laboratório de Referência em Triatomíneos e Epidemiologia da Doença de Chagas/CPqRR/FIOCRUZ. Av. Augusto de Lima 1715, Barro Preto, 30190-002 Belo Horizonte, Minas Gerais, Brasil.

Phone: 5531 3349-7762; Fax: 5531 3295-3115

e-mail: diotaiut@cpqrr.fiocruz.br

Received 24 March 2015

Accepted 18 June 2015 (e.g. oral transmission). Considering the large number of animal reservoirs of T. cruzi and the lack of drugs that may be used at a large scale, it is not possible to control the sources of infection through eradication schemes. The lack of immunizing do enables the control for the protection of susceptible populations. Thus, the only way to fight the vector is to improve the conditions at high risk sites by making domestic units impervious to the colonization of Triatomines (physical control), in parallel to the regular and systematic use of insecticides in infested dwellings (chemical control). Control programs in Latin American have traditionally focused on spraying insecticides on houses and household annexes ${ }^{(3)}$ (4).

In the 1920s, Brazil made the first prophylactic attempts to control domestic Triatomines, but with unsatisfactory results. Subsequently, experiments were carried out using pyrethrum powder, cyanide gas, flamethrowers, and caustic soda. However, these techniques were not used systematically because of the difficulty of large-scale application and their low residual effect on household annexes ${ }^{(5)}$. By the 1940s, little progress had been made in control of Chagas disease vectors. Thus, the discovery of synthetic insecticides represented a new possibility for vector control. Between the 1950s and the 1990s, various biological alternatives were tested to control Triatomines, but with no success. Examples included the use of nematodes, fungi, and hymenoptera egg predators ${ }^{(6)}$.

The first insecticides that were used to control Triatomine density were organochlorines ${ }^{(7)}$. In 1942, the first biological 
trials were conducted using dichloro-diphenyl-trichloroethane (DDT). Through field experiments, Lent \& Wygodzinsky ${ }^{(8)}$ demonstrated that the toxic action of this chemical was much more rapid in adult than in juvenile insects. This difference occurred because of the slow penetration of the product into the tegument of the nymph, with no ovicidal action. Consequently, DDT only protected dwellings against Triatomine reinfestation for three to four months. Dias \& Pellegrino ${ }^{(9)}$ demonstrated that DDT was ineffective at controlling insects through experiments on the susceptibility of Triatomines with DDT sprayed on different substrates, and by assessing the logistics of its largescale use. In contrast to DDT, hexachlorobenzene (HCB) was found to be effective at controlling Triatomines.

In 1947, Busvine \& Barnes ${ }^{(10)}$ observed significant mortality of Rhodnius prolixus exposed to HCB under laboratory conditions, but with little residual action. In field experiments, Dias \& Pellegrino ${ }^{(9)}$ found that HCB treatment was effective at eliminating Triatomine infestation for up to 5 months when applied at a dosage of $1 \mathrm{~g}$ of active ingredient $/ \mathrm{m}^{2}$, with at least in two spraying cycles at intervals of 30-60 days. In mid-1954, the National Malaria Service in Brazil tested dieldrin as a possible substitute for HCB. However, field experiments revealed high toxicity to handlers and domestic animals, as well as high cost, resulting in its use being discontinued ${ }^{(11)}$. In 1959, propoxur, a carbamate insecticide, was introduced to control Triatomines, because of its proven efficacy and ovicidal properties ${ }^{(12)}$. Bendiocarb, another insecticide from the same group, was also effective, and the World Health Organization (WHO) has previously suggested the combined use of the two products ${ }^{(13)}$.

In 1973, the organophosphate malathion was assessed, and its use was recommended mainly because of its ovicidal action $^{(14)(15)(16)}$. However, in addition to its short persistence in the environment, this product required higher application doses than those used for HCB and dieldrin organochlorines.

In the 1980 s, various pyrethroids proved to be effective insecticides, and have since been used to control of Chagas disease vectors. Pyrethroids are first-choice products because of their biodegradability, low-dose and easy application, and great residual action, lasting for almost one year in intra-domiciliary preserved conditions ${ }^{(17)}$. Theoretically, microencapsulated formulations enhance the residual action of insecticides; however, these expectations have yet to be confirmed ${ }^{(18)(19)}$.

Given the specificity of Triatomine occurrence in household annexes, but the absence of colonization, alternative means of vector control have been tested, including repellents ${ }^{(20)}$, lining, and/or impregnated curtains ${ }^{(21)(22)(23)}$. However, the effectiveness of these alternatives requires rigorous assessment. The invasion of Triatomines could potentially be controlled by physical barriers (since these insects are attracted to light), such as screens impregnated with insecticides.

Synthetic insecticide applications since the 1940s has advanced control of Chagas disease Triatomine vectors in domestic settings ${ }^{(24)}$. However, recently, areas with persistent reinfestation of Triatomines have been documented. This situation leads to two distinct, but equally concerning, scenarios. First, operating failures may hinder the control of
Triatomine populations, indicating an urgent need to: I) revise, in a systematically and strictly scientific manner, the tools and strategies of chemical control that have been available and/ or are in use since the discovery of Chagas disease until now; II) assess the triatomicide effect of diverse insecticides (chemical and formulation) so that they achieve the quality required to accomplish their purpose effectively; and III) invest in the training and development of health agents related to activities for the chemical control of Triatomines. Second, difficulty in controlling the disease may be due to the intrinsic features of Triatomine bugs, which makes them resistant to chemical agents. Thus, a better understanding of the biological, biochemical, molecular, and behavioral components of phenotype of resistance is required, which is the focus of the present review.

\section{METHODS}

This review was structured around a search of the peer-reviewed literature available on the PubMed database (http://www.ncbi. nlm.nih.gov) between 1970 and April 2015, using the keywords Insecticide resistance and Triatominae. All articles, monographs, master's theses, and doctoral dissertations had an abstract in English, Portuguese, or Spanish. The exclusion criteria were: I) reinfestation and difficulties of control vector strategies in the field without conducting laboratory bioassays; and II) residual bioassays evaluating the efficacy of different insecticides and/or formulations.

\section{RESULTS}

The search located 295 articles that were screened by title to select only those referring to laboratory bioassays. Out of the 295 articles, 262 were discarded based on the selection criteria. In all, 33 articles were retained for detailed analysis: qualitative/diagnostic dose bioassays ${ }^{(25)(26)(27)(28)(29)(30)(31)(32)(33)(34)(35)}$ and quantitative/ dose-response bioassays ${ }^{(25)}(26)(27)(28)(29)(30)(31)(32)(33)(34)(35)(36)(37)(38)$ (39) (40) (41) (42) (43) (44) (45) (46) (47) (48) (49) (50) (51) (52) (53) (54) (55) (56) (57) (Table 1).

\section{HISTORY OF TRIATOMINAE RESISTANCE TO INSECTICIDES}

Even a ninety decade, insecticide resistance of Triatomines was considered to be ad hoc and unlikely to occur because of their long life cycle (so even if resistant individuals exist, the selection process is expected to be very slow) and low genetic variability, which imply a low probability of individuals being less susceptible to insecticides genetically ${ }^{(58)}$. However, in the last 15 years there have been several reports of different Triatomine species exhibiting resistance to several insecticides (Table 1). This observation indicates that this phenomenon more widespread than expected, requiring better characterization and delimitation. Most available published studies refer to Triatoma infestans populations with high resistance ratios $50 \%\left(\mathrm{RR}_{50}\right)$ in Bolivia and Argentina, which are areas where vector control is difficult $\left(\sim \mathrm{RR}_{50}>50.0\right)$. Research on the susceptibility of Triatomines in Venezuela, Colombia, and Paraguay remain ad hoc, focusing on the vector control of Rhodnius prolixus, T. infestans, T. maculata, T. dimidiata, and Panstrongylus herreri. In Brazil, increasing numbers of studies are investigating the susceptibility of Triatomines to insecticides and have been focused on T. brasiliensis, T. sordida, P. megistus, and T. infestans collected 
TABLE 1 - Reports of Triatominae resistance to insecticides.

\begin{tabular}{|c|c|c|c|c|}
\hline Triatominae & Country & Standardization of insects & Insecticide & Reference \\
\hline Triatoma sordida & Brazil & F1, NI, 5d old, fasting $(1.2 \pm 0.2 \mathrm{mg})$ & Deltamethrin & 25 \\
\hline Triatoma infestans & Argentina & $\begin{array}{l}\text { F1, eggs/NI, } 11-12 \mathrm{~d} / 5-7 \mathrm{~d} \text { old, } \\
\text { fasting }(1.3 \pm 0.2 \mathrm{mg})\end{array}$ & $\begin{array}{l}\text { Deltamethrin, Amitraz, } \\
\text { Fenitrothion, Flubendiamide, Imidacloprid } \\
\text { Indoxacarb, Ivermectin, Spinosad }\end{array}$ & 26 \\
\hline Triatoma infestans & Bolivia & F1, NI, 5d old, fasting $(1.74 \pm 0.28 \mathrm{mg})$ & Deltamethrin & 27 \\
\hline Triatoma infestans & Argentina & $\mathrm{F} 1, \mathrm{NI}, 5-7 \mathrm{~d}$ old, fasting $(1.3 \pm 0.2 \mathrm{mg})$ & Deltamethrin, Fenitrothion & 29 \\
\hline Triatoma infestans & Bolivia & F1, NI, 5d old, fasting $(1.2 \pm 0.2 \mathrm{mg})$ & Deltamethrin & 30 \\
\hline Triatoma sordida & Brazil & F1, NI, 5d old, fasting $(1.2 \pm 0.2 \mathrm{mg})$ & Deltamethrin & 31 \\
\hline Triatoma sordida & Brazil & F1, NI, 5d old, fasting $(1.3 \pm 0.2 \mathrm{mg})$ & Deltamethrin & 32 \\
\hline $\begin{array}{l}\text { Triatoma infestans } \\
\text { Rhodnius prolixus }\end{array}$ & $\begin{array}{c}\text { Brazil } \\
\text { Venezuela }\end{array}$ & $\begin{array}{l}\text { F1, NI, 3d old, fasting }(1.2 \pm 0.2 \mathrm{mg}) \\
\text { F1, NI, 24-36h old, fasting }(0.5 \pm 0.1 \mathrm{mg})\end{array}$ & $\begin{array}{l}\text { Deltamethrin, Beta-cyfluthrin, } \\
\text { Beta-cypermethrin, Lambda-cyhalothrin, } \\
\text { Cypermethrin, Dieldrin }\end{array}$ & 36 \\
\hline $\begin{array}{l}\text { Triatoma infestans } \\
\text { Rhodnius prolixus }\end{array}$ & Argentina & $\begin{array}{l}\text { F1, NI, } 5-7 \mathrm{~d} \text { old, fasting }(1.2 \pm 0.2 \mathrm{mg}) \\
\text { F1, NI, } 24-36 \mathrm{~h} \text { old, fasting }(0.5 \pm 0.1 \mathrm{mg})\end{array}$ & $\begin{array}{l}\text { Deltamethrin, Beta-cyfluthrin, } \\
\text { Beta-cypermethrin, Cypermethrin, } \\
\text { Lambda-cyhalothrin }\end{array}$ & 37 \\
\hline Triatoma infestans & Argentina & F1, NI, 3d old, fasting $(1.2 \pm 0.2 \mathrm{mg})$ & Deltamethrin & 38 \\
\hline $\begin{array}{l}\text { Triatoma infestans } \\
\text { Panstrongylus herreri }\end{array}$ & Peru & $\mathrm{F} 1$, adult/NV & $\begin{array}{l}\text { Cyfluthrin, Beta-cyfluthrin, Cypermethrin, } \\
\text { Alfa-Cypermethrin, Deltamethrin }\end{array}$ & 39 \\
\hline Triatoma infestans & $\begin{array}{l}\text { Argentina } \\
\text { Bolívia }\end{array}$ & F1, NI, 3d old, fasting $(1.2 \pm 0.2 \mathrm{mg})$ & $\begin{array}{l}\text { Fenitrothion, Deltamethrin, Fipronil, } \\
\text { Bendiocarb }\end{array}$ & 43 \\
\hline Triatoma infestans & $\begin{array}{l}\text { Argentina } \\
\text { Bolívia }\end{array}$ & $\begin{array}{l}\mathrm{F} 1 \text {, eggs/NI, } 11-12 \mathrm{~d} / 5-7 \mathrm{~d} \text { old, } \\
\text { fasting }(1.3 \pm 0.2 \mathrm{mg})\end{array}$ & $\begin{array}{l}\text { Deltamethrin, Fenitrothion, } \\
\text { Lambda-cyhalothrin, Fipronil }\end{array}$ & 44 \\
\hline Triatoma infestans & Brazil & F1, NI, 3d old, fasting $(1.2 \pm 0.2 \mathrm{mg})$ & Deltamethrin & 45 \\
\hline Triatoma infestans & Argentina & F1, NI, 3-5d old, fasting $(1.2 \pm 0.2 \mathrm{mg})$ & Deltamethrin & 46 \\
\hline Triatoma infestans & $\begin{array}{l}\text { Argentina } \\
\text { Paraguay } \\
\text { Bolivia }\end{array}$ & $\mathrm{F} 1, \mathrm{NI}, 3-5 \mathrm{~d}$ old, fasting $(1.2 \pm 0.2 \mathrm{mg})$ & Deltamethrin, Fipronil & 47 \\
\hline Triatoma infestans & Bolívia & F1, NI, 3-5d old, fasting $(1.69 \pm 0.31 \mathrm{mg})$ & Deltamethrin, Bendiocarb, Malathion & 48 \\
\hline $\begin{array}{l}\text { Triatoma brasiliensis } \\
\text { Panstrongylus megistus }\end{array}$ & Brazil & F1, NI, 3d old, fasting $(1.2 \pm 0.2 \mathrm{mg})$ & Deltamethrin & 49 \\
\hline Triatoma brasiliensis & Brazil & F1, NI, 5d old, fasting $(1.2 \pm 0.2 \mathrm{mg})$ & Deltamethrin & 50 \\
\hline Triatoma sordida & Brazil & F1, NI, 3d old, fasting $(1.2 \pm 0.2 \mathrm{mg})$ & Deltamethrin & 51 \\
\hline Triatoma infestans & Bolivia & F1, NI, 5-7d old, fasting $(1.3 \pm 0.2 \mathrm{mg})$ & Fipronil, Deltamethrin & 52 \\
\hline Triatoma infestans & Argentina & F1, NI, $3-5 \mathrm{~d}$ old, fasting $(1.3 \pm 0.2 \mathrm{mg})$ & Deltamethrin & 53 \\
\hline
\end{tabular}


TABLE 1 - Continuation.

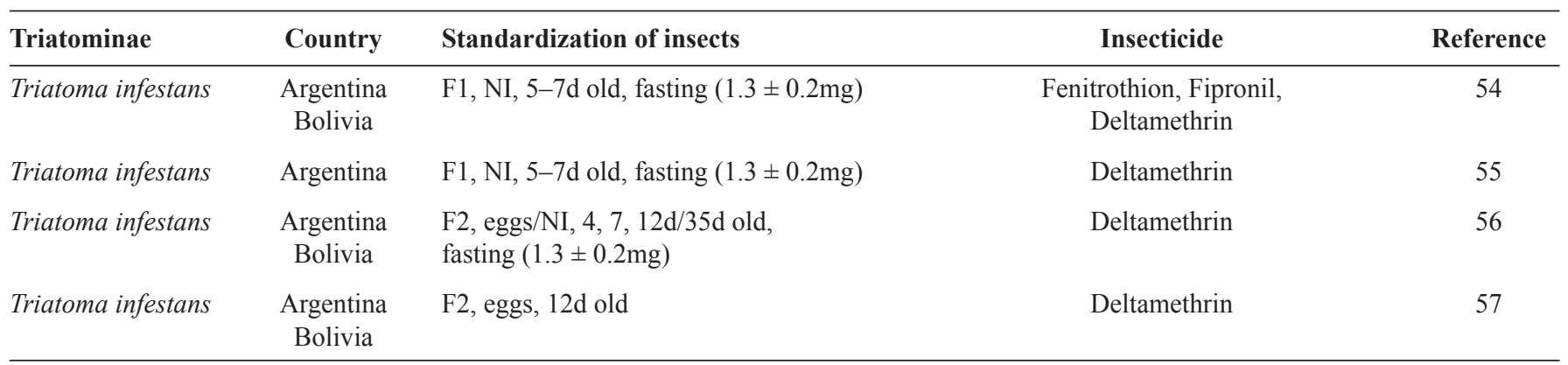

F1: first generation; F2: second generation; NI: first instar nymph; NV: fifth instar nymph; d: days; mg: milligrams; h: hours.

in areas with reports of persistent triatominic infestations. Of note, triatominic populations in Brazil have shown low $\mathrm{RR}\left(\mathrm{RR}_{50}<8.0\right)$ to date.

Insecticide resistance results in a decrease in the mortality observed in a population subjected to continuous treatment. This characteristic is expressed by a greater number of specimens that tolerate lethal doses compared with specimens considered sensitive during the initial application of the product, leading to selection pressure in populations. This phenomenon is based on the genetic variability of natural populations. Consequently, this variability combined with insecticide pressure results in the selection of certain phenotypes and the subsequent increase in their frequencies ${ }^{(59)}$.

Insecticide resistance of Triatominae is a characteristic that is inherited in an autosomal and semi-dominant manner. There is evidence that a polygenic number of genes involved in the resistance phenomenon ${ }^{(46)}$. The maintenance of different insecticide susceptibility profiles in Brazilian T. sordida field populations, collected in areas with continue insecticide pressure, was demonstrated by Pessoa ${ }^{(25)(28)}$. This phenomenon may be related to the long life cycle of $T$. sordida, the occurrence of colonies originating from a small number of specimens, and reduced genic flow between populations. Like other biological models, the dynamics of the evolution of resistance depend on the population biology of a given species, the level of exposure to the insecticide, and the number of individuals influenced by these factors without coming into contact with the active ingredients of the chemical, including gene flow between populations in the treated and non-treated areas.

Germano et al. ${ }^{(60)}$ investigated the reproductive and developmental costs of deltamethrin resistance in $T$. infestans from the Argentinean Gran Chaco eco-region in Araguary, Province of Salta. In an environment without insecticides, reproductive cost was expressed as lower fecundity, while developmental cost was expressed as a shorter duration of the second and third nymphal stages and an extension of the fifth nymphal stage.

Several authors have demonstrated that the same triatominic population exhibits different toxicological profiles when exposed to the same chemical class of insecticide. In Argentina, high levels of resistance to deltamethrin, beta-cypermethrin, beta-cyfluthrin, and lambda-cyhalothrin were detected in four T. infestans populations from El Chorro, El Sauzal, Salvador Mazza, and La Toma, without noticeable involvement of monooxygenases in the resistance phenotype ${ }^{(40)}$. However, no population was resistant to fenitrothion. Sfara et al. ${ }^{(41)}$ assessed the toxicity of deltamethrin, lambda-cyhalothrin, and tetramethrin on T. infestans populations collected from El Chorro and La Toma, in addition to the effect of these insecticides on insect locomotor activity. The test populations exhibited cross-resistance to the three pyrethroids, while deltamethrin caused hyperactivity. Despite the resistance to the tested pyrethroids, sensory processing of repellency caused by N,N-Diethyl-meta-toluamide (DEET) appeared to remain unchanged in these populations.

Different toxicological profiles were also observed when populations were exposed to different chemical classes of insecticides. Santo Orihuela et al. ${ }^{(43)}$ characterized the susceptibility of Argentinean (Salta and La Rioja) and Bolivian (Yacuiba) populations of T. infestans to deltamethrin, fenitrothion, fipronil, and bendiocarb. All populations were resistant to deltamethrin $\left(\mathrm{RR}_{50} 14.09-154.4\right)$ only, without any noticeable involvement of monooxygenases in the resistance phenotype. However, some studies assessing the susceptibility of $T$. infestans to insecticides belonging to a different class demonstrated cross-resistance. Carvajal et al. ${ }^{(26)}$ assessed the toxicity of different insecticides on deltamethrin susceptible and resistant populations of T. infestans from El Malá. Both populations proved susceptible to fenitrothion and imidacloprid, but were resistant to amitraz, flubendiamide, ivermectin, indoxacarb, and spinosad. Lardeux et al. ${ }^{(48)}$ characterized the susceptibility of 50 Bolivian populations of T. infestans to deltamethrin, malathion, and bendiocarb. All populations showed significant levels of resistance to deltamethrin $\left(\mathrm{RR}_{50}\right.$ 6.0-491.0). However, resistance to bendiocarb $\left(R_{50} 1.8\right)$ and malathion $\left(R_{50} 1.2\right)$ was not observed. For populations resistant to deltamethrin, tests using inhibitors of monooxygenases failed to completely reverse the observed resistance, suggesting that other mechanisms are involved in the resistance phenotype.

The toxicological profile observed in eggs cannot be transposed to first instar nymphs, demonstrating the intrinsic characteristics of the different developmental stages. Toloza et al. ${ }^{(44)}$ characterized the resistance profile of the eggs and first instar nymphs 
(NI) of Argentinean (Salvador Mazza and Valle Viejo) and Bolivian (Mataral, Sucre, and Yacuiba) populations of $T$. infestans to different insecticides. At the egg stage, only the Salvador Mazza population was resistant to lambda-cyhalothrin $\left(R_{50} 14.2\right)$, but was susceptible to fipronil and fenitrothion. In comparison, the Mataral and Sucre (Bolivia) populations were susceptible to all insecticides. However, the first instar nymphs (NI) of the Salvador Mazza populations was highly resistant to lambda-cyhalothrin $\left(\mathrm{RR}_{50} 106.2\right)$, but these populations were susceptible to the other insecticides. All Bolivian populations were susceptible to all insecticides, except the nymphs of Sucre, which were highly resistant to fipronil $\left(\mathrm{RR}_{50} 585.5\right)$. Germano et al. ${ }^{(54)}$ identified different toxicological profiles in Argentinean (Acambuco) and Bolivian (Mataral and Entre Rios) populations of $T$. infestans to deltamethrin, fipronil, and fenitrothion. Tests with NI revealed that all populations were resistant to all insecticides, except for the population from Entre Rios, which was susceptible to fipronil. Conversely, tests performed with eggs using deltamethrin showed resistance in all populations, with esterases being involved in the resistance phenotype. Roca-Acevedo et al. ${ }^{(56)}$ assessed the susceptibility of developing eggs and newly hatched nymphs in the regions of Campo Largo (Argentina) and Entre Rios (Bolivia), which were suspected of insecticide resistance. In both populations, the first instar nymphs were resistant to deltamethrin $\left(\mathrm{RR}_{50} 1,108\right.$ Campo Largo and $\mathrm{RR}_{50}$ 173.0 Entre Rios). Compared with the Susceptibility Reference Lineage (SRL), the efficacy of deltamethrin was significantly lower on the eggs. Santo-Orihuela et al. ${ }^{(57)}$ characterized the susceptibility of $T$. infestans eggs collected from wild and domestic areas of Argentina (Salta) and Bolivia (Potosi, Cochabamba, and Tarija) to deltamethrin. The $\mathrm{RR}_{50}$ values ranged from 0.5-44.9. In resistant populations, esterase did not appear to be involved in the resistance phenotype.

The toxicity profile observed in nymphs cannot be applied to triatomines belonging to different developmental stages. Zerba et al. ${ }^{(35)}$ assessed the susceptibility of two Argentinean populations of $T$. infestans, at different stages of development to beta-cypermethrin and deltamethrin. Beta-cypermethrin had a better effect on fifth instar nymphs (NV), whereas deltamethrin had a better effect on adults. The results showed the equivalent efficacy of beta-cypermethrin to control T. infestans infestation when applied at $50 \mathrm{mg} / \mathrm{m}^{2}$ compared with deltamethrin applied at $25 \mathrm{mg} / \mathrm{m}^{2}$. Reyes et al. ${ }^{(42)}$ characterized baseline susceptibility to deltamethrin, beta-cypermethrin, and fenitrothion to T. maculata from San Jose and T. dimidiata from San Joaquin (Colombia). Studies with the NI of T. maculata obtained a Lethal Dose $50 \%\left(\mathrm{LD}_{50}\right)$ of $0.07,0.05$, and $4.12 \mathrm{ng}$ a.i./treated nymphs for deltamethrin, beta-cypermethrin, and fenitrothion, respectively, a Lethal Dose $99 \%\left(\mathrm{LD}_{99}\right)$ of of $1.08,0.37$, and 17.89, respectively. Studies with the NI of T. dimidiata obtained a $\mathrm{LD}_{50}$ of $0.44,0.46$, and $16.45 \mathrm{ng}$ a.i./treated nymphs for deltamethrin, beta-cypermethrin, and fenitrothion, respectively, and a $\mathrm{LD}_{99}$ of $2.22,1.97$, and 36.07 , respectively. For the NV of $T$. dimidiata, studies obtained a $\mathrm{LD}_{50}$ of $510.72,1,623.59$, and $838.91 \mathrm{ng}$ a.i./treated nymphs for deltamethrin, betacypermethrin, and fenitrothion, respectively, and a $\mathrm{LD}_{99}$ of $9,607.50,11,717.91$, and 1,525.0 respectively.
Toxicological profiles differ across regions and even within the microgeography of the same location. Germano et al. ${ }^{(55)}$ assessed the susceptibility of Triatomine populations collected from two domestic units in Acambuco (Argentina) to deltamethrin. Pessoa et al. ${ }^{(31)(33)(34)}$ investigated the susceptibility of different Brazilian populations of T. sordida $\left(\mathrm{RR}_{50} 0.72-6.8\right)$, T. infestans $\left(\mathrm{RR}_{50} 1.74-3.26\right)$, and T. brasiliensis $\left(\mathrm{RR}_{50} 0.32-1.21\right)$ to deltamethrin collected in areas with persistent triatominic infestations, despite the existence of chemical control, characterizing them as susceptible to the tested insecticide. The different susceptibility profiles in different domestic units from the same localities suggest that the geographical structuring of the resistance phenotype differs between sites and within sites at the microgeographical level. These differences are caused by differences in the resistant foci profiles of $T$. infestans, indicating the occurrence of independent evolutionary processes. Despite the reduced triatominic dispersion capacity, these observations demonstrate the inadequacy of transposing results from one population to another, even when geographically near to one another.

The toxicological profiles shown by sylvatic populations of T. infestans represent natural or wild toxicological phenotypes, and may be used to determine tolerance to different insecticides. Roca Acevedo et al. ${ }^{(52)}$ characterized the susceptibility profile of four wild T. infestans populations collected from the Andean valleys of Bolivia (Mataral, Kirus-Mayu, 20 de Octubre, and Ilicuni), to deltamethrin and fipronil. All populations were resistant to deltamethrin $\left(\mathrm{RR}_{50} 1.9-17.4\right)$, with no indication that monooxygenases were present in resistant populations. In trials with fipronil, the susceptibility of a domestic population of $T$. infestans collected from Mataral was also assessed; the $\mathrm{RR}_{50}$ ranged from 0.5 to 45.6 in the wild populations and ranged from 139.2 in the domestic population. Depickére et al. ${ }^{(27)}$ characterized the susceptibility of 20 Bolivian populations collected from La Paz, Cochabamba, Potosi, Santa Cruz, and Tarija (12 wild populations and 8 domestic populations) to deltamethrin. The dose-diagnostic tests revealed that all wild populations were susceptible to deltamethrin, except for the Julo Grande population (Toro-Toro/Potosi). Among the domestic populations, only three were susceptible to deltamethrin. The populations that were indicative of resistance were subjected to dose response trials, revealing wide variation in susceptibility $\left(\mathrm{RR}_{50} 3.8-818.0\right)$. Gomez et al. ${ }^{(30)}$ assessed the susceptibility of 9 populations from Gran Chaco and the Inter-Andean valleys of Bolivia (5 wild populations and 4 domestic populations) to deltamethrin. The wild populations showed low variation in susceptibility $\left(\mathrm{RR}_{50} 0.62-4.24\right)$, whereas wide variation in susceptibility was detected for the domestic populations $\left(\mathrm{RR}_{50} 2.9-129.1\right)$. The geographical origin and distribution epicenter of T. infestans is located in the Cochabamba Valley (Bolivia) ${ }^{(60)(61)(62)}$; thus, it is possible that the toxicological profile of the sylvatic populations from Cochabamba represents its ancestral toxicological profile. Therefore, $T$. infestans from different geographical areas may exhibit different toxicological phenotypes, even in the absence of insecticide selection. Consequently, this variation may determine differences in T. infestans susceptibility to insecticides. Germano et al. ${ }^{(47)}$ characterized the susceptibility of $T$. infestans to deltamethrin and fipronil. The authors collected specimens from areas 
surrounding regions with resistance to pyrethroids in Bolivia (Tarija), Argentina (Salta, Catamarca, Santiago Del Estero, Chaco, and Santa Fe), and Paraguay (Boquerón). The Tarija populations were highly resistant to deltamethrin $\left(R_{50}\right.$ 247.4-541.6), whereas those in Argentina had moderate $R_{50}$ $\left(\mathrm{RR}_{50}\right.$ 0.1-39.0), and those in Paraguay had a low change in susceptibility $\left(\mathrm{RR}_{50} 3.7\right)$. The Argentinean populations were susceptible to fipronil $\left(\mathrm{RR}_{50} 1.09-3.0\right)$, whereas the profiles from Argentina were varied $\left(\mathrm{RR}_{50} 0.19-92.7\right)$, being mostly resistant.

\section{MECHANISMS INVOLVED WITH INSECTICIDE RESISTANCE IN TRIATOMINAE}

The mechanisms involved with Triatomines resistance to insecticides are related to changes in one or several toxicokinetic/ toxicodynamic steps occurred during the interaction between insect-insecticide, isolated or associated, being: I) changes in the local of the chemical active penetration; II) increase in its enzymatic detoxification; and III) changes in the action ${ }^{(63)}$.

Physiological resistance is associated with a reduction in the penetration of insecticides because of changes to the insect cuticle and/or in their ability to store/excrete the insecticide ${ }^{(64)}$. Mougabure Cueto et al. ${ }^{(64)}$ compared the insecticide activity of 1-dodecanol on the development of the cuticle in $R$. prolixus T. infestans. The authors found that recently hatched first instar nymphs (1-3h old) were more vulnerable than older ones (24-36h old). Pedrini et al. ${ }^{(65)}$ used scanning electronic microscopy to show that Argentinean populations of $T$. infestans resistant to deltamethrin have thicker exoskeletons $(32.1 \pm 5.9 \mu \mathrm{m})$ than susceptible populations $(17.8 \pm 5.4 \mu \mathrm{m})$. Thicker cuticles enriched in hydrocarbons probably restrict deltamethrin penetration in resistant insects. These studies indicate that the cuticle is an important variable in the intoxication of insects, representing the first barrier to insecticides before reaching target sites within the insect body ${ }^{(66)}$.

Biochemical resistance corresponds to a significant increase in the activities of detoxification enzymes, especially

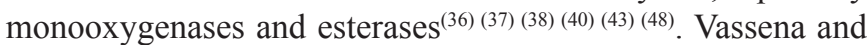
Picollo ${ }^{(42)}$ assessed the susceptibility of a $R$. prolixus population from Carabobo (Venezuela) and a T. infestans population from Rio Grande do Sul (Brazil) to deltamethrin, beta-cypermethrin, beta-cyfluthrin, lambda-cyhalothrin, and cypermethrin. The R. prolixus population had an $\mathrm{RR}_{50}$ of 3.0-12.4, whereas that of the $T$. infestans population was lower, ranging from 0.92 to 7.0 . In both cases, there was an increase in monooxygenases related to the Susceptibility Reference Lineage (SRL). Gonçalves Audino et al. ${ }^{(43)}$ characterized the toxicological profile to deltamethrin of 4 T. infestans populations from Mendoza, Catamarca, Salta and San Luis to deltamethrin, and obtained $\mathrm{RR}_{50}$ ranging from 2.0 to 7.8 . For the population with $R_{50} 7.8$, biochemical tests indicated the possible involvement of esterases and monooxygenases in the observed phenotype. Studies developed by Pessoa ${ }^{(28)}$ using $T$. sordida populations with different susceptibility profiles to deltamethrin $\left(\mathrm{RR}_{50} 1.22-6.5\right)$ showed an increase in esterase and monooxygenase activity. This increased activity may contribute to the lower susceptibility of Triatomines to deltamethrin. Despite the results obtained by different studies, a limited number of substrates was used in the enzymatic assays, particularly when compared to the great diversity present in insects, in addition to the fact that many of the assessed enzymes are multifunctional. Therefore, the populations may detoxify certain pesticides by activating different enzymes from the same class. This issue was investigated by Saavedra-Rodrigues et al. ${ }^{(67)}$ using the microarray technique, in which the authors used a large number of substrates in population studies of Aedes aegypti exhibiting different susceptibility profiles to permethrin. This characteristic has the potential of generating different specific responses around the interaction of each population with each insecticide, preventing what is defined as a general diagnostic profile related to resistance. Moreover, these studies showed the absence of a numeric correlation between the $\mathrm{RR}_{50}$ values of the populations in response to deltamethrin and the change in the percentage of various detoxifying enzymes.

Concerning changes to the insecticide site of action in Triatominae, Fabro et al. ${ }^{(53)}$ and Capriotti et al. ${ }^{(68)}$ reported the existence of two punctual mutations (L1014F and L925I) in the second domain of the sodium channel gene protein in two different Argentinean populations of $T$. infestans with high resistance levels. Mutation L9251I seems to be associated with much higher $\mathrm{RR}_{50}$ than that observed for mutation L1014F.

\section{METHODOLOGICAL DIFFICULTIES}

Three major obstacles have been identified when interpreting the results obtained by studies on Triatomines resistance to insecticides; namely: I) a wide range of methodologies, despite the existence of a single guiding protocol ${ }^{(27)(36)(38)(42)(43)(46)(47)(53)(55)(56)}$; II) a lack of information about the real impact of resistance ratios in the field; and III) the concept of the Susceptibility Reference Lineage (SRL). The first shortcoming of studies on Triatominae resistance to insecticides is that, at present, there is only one guiding protocol for studies on insect susceptibility to insecticides, i.e., the one provided by the $\mathrm{WHO}^{(69)}$. However, a large variety of methodologies has been used, preventing the direct comparison of results and, in a more practical way, a clear comprehension of the real impact of these results in field vector control strategies. Consequently, Pessoa et al. ${ }^{(32)}$ redefined the following technical details: place to apply insecticide on insects (abdomen, dorsal or ventral position), age (1,3, and 5 days after hatching) and insect generation (F1 and F2), appropriate moment to perform mortality record (24-96h), and appropriate diagnostic dose to detect resistance in laboratory qualitative testing ( $1 \mathrm{x}$ and $2 \mathrm{xLD}_{99}$ of SRL). Bioassays are not influenced by the place of insecticide application or by the generation of the study population. Furthermore, 3-day-old nymphs are less susceptible to treatment with insecticides, which is probably attributed to their energy reserves and the complete formation of the exoskeleton. The protocol proposed by $\mathrm{WHO}^{(69)}$ recommends that the mortality reading should be performed $72 \mathrm{~h}$ after treatment with pyrethroid. Many of the published studies performed the mortality reading with $24 \mathrm{~h}$, disregarding the knockdown effect - momentary paralysis, which may or may not be followed by full motor recovery ${ }^{(70)}$. Thus, mortality may have been incorrectly recorded, as insects in a knockdown state may have subsequently recovered, underestimating the lethal doses encountered and the derived resistance ratio. Of note, this issue is not relevant for chemical ingredients belonging to other 
chemical groups, because only pyrethroids have a knockdown effect. Therefore, when using pyrethroids, the mortality record must be performed $72 \mathrm{~h}$ after treatment to allow for knockdown recovery.

The diagnostic-dose (DD) is a tool that allows population vigor to be determined in the field compared with the susceptibility reference lineage. In studies with triatomines, although the use of $1 \mathrm{xLD}_{99}$ was recommended by $\mathrm{WHO}^{(69)}$, some authors adopted $2 \mathrm{xLD}_{99}{ }^{(71)}$, as recommended for mosquitoes. The results with DD $2 x^{2} D_{99}$ invariably generated $100 \%$ mortality, resulting in the high mortality of insects with altered susceptibility. However, the studies performed by Pessoa ${ }^{(32)}$ demonstrated that the use of $1 \mathrm{xLD}_{99}$ is more appropriate, because it allows a positive correlation to be established between the detected mortality and population susceptibility, indicated by the resistance ratios. Furthermore, the results indicating resistance in the tests using the diagnostic-dose may be false-positive, i.e., laboratory tests indicate possible resistance that is not confirmed in field trials; however, the opposite was not observed.

Sample size also presents another relevant issue regarding the use of DD as a screening tool for possible field populations with altered susceptibility. The use of 10 nymphs is recommended for each test, in triplicate ${ }^{(69)}$. Yet, Amelotti et al. ${ }^{(72)}$ demonstrated that a single female, kept isolated throughout its life cycle, has the potential to generate more resistant offspring when younger, and more susceptible descendants as it ages. This issue reveals the complexity of genetic variability at the individual level; thus, providing insights about the impact of such variation in the population context.

The RR is also subject to two interpretations. Zerba and Picollo ${ }^{(73)}$ suggest that populations with $\mathrm{RR}_{50}>2.0$ are resistant, whereas the Pan-American Health Organization (PAHO) $)^{(74)}$ states that populations with $\mathrm{RR}_{50}>5.0$ are resistant. The $\mathrm{RR}$ is calculated from SRL lethal doses; thus, the resistance level obtained may consequently interfere, in the future developments to be adopted by the managers involved with Triatominae control in the field. As an example, the $\mathrm{RR}_{50}$ observed by Obara et al. ${ }^{(51)}$ for $T$. sordida populations treated with deltamethrin allowed the study population to be classified as susceptible to the tested insecticide, leading to the recommendation of time line monitoring. However, if the authors had used the SRL adopted by Pessoa ${ }^{(31)}$, the $\mathrm{RR}_{50}$ would have increased nine fold. Under this scenario, the populations would have been classified as resistant, and the insecticide used should have been replaced with an insecticide with a different action mode.

Therefore, it is important to adopt a single SRL per species that should be used by all research groups. However, it is not possible to maintain this SRL in the laboratory ad infinitum without the inclusion of external material. Furthermore, such criteria are highly arbitrary and empirical, with insufficient theoretical and practical grounding. Therefore, it is necessary to perform simultaneous and complementary laboratory and field bioassays to correlate the two. It would then be possible to set cut-offs to distinguish susceptibility from resistance. In the field, Triatomine susceptibility must be reviewed on a time line, considering the continuous pressure of selection in areas requiring continuous chemical treatments.
The final issue is the methodological criteria recommended by PAHO to choose a SRL - a colony with more than five generations in the laboratory, without contact with insecticides and no inclusion of external material and/or the colony collected from a location where there was no treatment with insecticide whatsoever ${ }^{(74)}$. The meeting of field populations more susceptible than the SRL ${ }^{(25)(28)(30)(33)}$ reveal the fragility of this criteria.

\section{FACTORS ASSOCIATED WITH INSECTICIDE RESISTANCE}

Triatominae resistance to insecticides may be linked to: I) the behavioral characteristics of these insects associated with their numerous peridomestic refuges; II) the characteristics of pyrethroid insecticides; and III) operational flaws, such as incorrect insecticide dosage, frequency, and application time.

The persistence of some Triatomine specimens, mainly in the peridomestic environment, despite successive insecticides spraying on the timeline, may be related to the behavior of these insects. The peridomicile presents a wide variety of ecotopes that correspond to an infinite number of hiding places associated with different sources of food for T. sordida, such as chickens, dogs, pigs, and cats. Spraying the peridomicile is exhausting work, with the unstacking all accrued material being operationally impossible for responsible field agents ${ }^{(75)}$.

Pyrethroids provide limited residual effect on the peridomicile, with lethal doses on treated surfaces being highly transitory ${ }^{(17)}$. This outcome is expected, as the most used conventional formulations are wettable powders and suspension concentrates, which represent the only a vehicle for active ingredients and do not provide protection against a wide range of agents. Such agents include air, ultraviolet radiation, moisture, or physical factors, such as rain, wind, and other agents, including humans and domestic animals, which promote the erosion of the surfaces treated by removing deposited insecticides. The chemical loss of pyrethroids is expected on highly alkaline surfaces or when exposed to ultraviolet radiation. Furthermore, according to the nature of various structures (porosity and alkalinity), different penetration mechanisms and insecticide absorption may be observed. On porous surfaces, the chemical ingredient is deposited and seems to lose activity faster than on other surfaces, such as wooden boards and ceramic tiles. These environmental variables directly influence the insecticide degradation rate and the consequent need for reapplication to maintain domestic units that are free of triatomine infestation. However, during routine activity, a point-to-point assessment of these variables is not possible, in which specific treatment frequencies could be reset for each region. Thus, the inflow of triatomines from external sources, triatomine survivors from previous applications, and the hatching of eggs leads to the recolonization of houses, as well as an increase in population genetic diversity and possible resistance. Migration into the area may also lead to the possible dilution of the observed resistance ratios, which may be underestimated.

Finally, operational failures may cause the observed difficulty in controlling triatomines, revealing the urgent need 
for technical improvement of the field team in charge. Control failures may be caused by a lack of efficacy of the insecticide, by operational failures, and/or environmental conditions. The lack of efficacy of the insecticide is related to the poor quality of the active ingredient and/or inadequate formulation. Operational failures include insecticide dilution errors, application failure, and problems with spraying machines. There may also be a lack of continuity in spraying cycles, due to administrative, budgetary, and logistical reasons ${ }^{(74)}$.

Yet, the disjointed overlap of endemic control programs (malaria, leishmaniasis, Chagas disease) and use of insecticides for agriculture or domestic purposes may generate selection pressure on Triatomine populations, favoring the survival of the most resistant individuals ${ }^{(76)(77)}$.

\section{CONCLUSIONS}

Even a ninety decade, insecticide resistance of triatomines was considered ad hoc and unlikely to occur, due to their long life cycle and low genetic variability. However, in the last 15 years, several studies have reported the resistance of different Triatomine species to several insecticides; thus, this phenomenon is more widespread than previously assumed, requiring better characterization and delimitation. Insecticide resistance of Triatominae is a characteristic inherited in an autosomal and semi-dominant manner, and has been detected in both in domestic and sylvatic populations. There is evidence that a polygenic number of genes are involved in resistance. The insecticide phenotype has reproductive and developmental costs to Triatominae. The toxicological profile observed in eggs cannot be transposed to different developmental stages. There are different toxicological profiles at the macro- and microgeographical level. The toxicological profiles exhibited by sylvatic populations of $T$. infestans can represent natural and wild toxicological phenotypes that determine tolerance to different insecticides. There are various physiological resistance mechanisms, including: I) reduced penetration of insecticide resulting from changes to insect cuticle; II) changes in the activity of different enzymes, with variation in the proportions and combinations, but with a significant increase in monooxygenases and esterases; and III) two point mutations (L1014F and L925I) in the second domain of the sodium channel gene protein. Studies of Triatomine resistance to insecticides highlight 3 limitations in the interpretation of results; namely, I) there is wide diversity in methodologies, despite the existence of a single guiding protocol; II) there is a lack of information about the actual impact of resistance ratios in the field; and III) the viability of the methodological criterion used for choosing the susceptibility reference lineage, since some field populations are more susceptible to the SRL ${ }^{(25)(28)(30)(33)}$. Because it is a complex phenomen and most often multifactorial, we believe that insecticides resistance in triatomine should be evaluated by the eco-epidemiological and environmental context in which Triatomine belong. If identified early, the resistance can be managed through different strategies (eg. insecticides substituition) to minimize or even reverse the observed phenotype.

\section{CONFLICT OF INTEREST}

The authors declare that there is no conflict of interest.

\section{FINANCIAL SUPPORT}

Financial support was provided by the Conselho Nacional de Desenvolvimento Científico e Tecnológico (CNPq), Fundação de Amparo a Pesquisa do Estado de Minas Gerais (FAPEMIG), Centro de Pesquisas René Rachou (CPqRR), Fundação Oswaldo Cruz (FIOCRUZ), Secretaria de Vigilância em Saúde (SVS), Ministério da Saúde (MS) - Brazil, - and World Health Organization (WHO).

\section{REFERENCES}

1. Moncayo A, Silveira AC. Current epidemiological trends for Chagas disease in Latin America and future challenges in epidemiology, surveillance and health policy. Mem Inst Oswaldo Cruz 2009; 104:17-30.

2. World Health Organization (WHO). Chagas disease (American trypanosomiasis) (Internet). WHO; 2015 (Accessed 2015 March 11). Available at http://www.who.int/mediacentre/ factsheets/fs340/en/

3. Coura JR, Dias JCP. Epidemiology, control and surveillance of Chagas disease -100 years after its discovery. Mem Inst Oswaldo Cruz 2009; 104:31-40.

4. Coura JR, Viñas PA. Chagas disease: a new worldwide challenge. Nature 2010; 465:S6-S7.

5. Dias JCP. O controle da doença de Chagas no Brasil. In: Silveira $\mathrm{AC}$, editor. O controle da doença de Chagas nos países do Cone Sul da America: uma iniciativa internacional. Organização Pan-Americana da Saúde/Faculdade de Medicina do Triângulo Mineiro; 2002. p. 145-250.

6. Dias JCP, Schofield CJ. The evolution of Chagas disease (American Trypanosomiasis) control after 90 years since Carlos Chagas Discovery. Mem Inst Oswaldo Cruz 1999; 94:103-121.

7. Pinchin R, Oliveira Filho AM, Pereira ACB. The flushing-out activity of pyrethrum and synthetic pyrethroids on Panstongylus megistus. Trans Roy Soc Trop Med Hyg 1980; 74:801-803.

8. Lent H, Wygodzinsky PW. Revision of the Triatominae (Hemiptera, Reduviidae), and their significance as vectors of Chagas' disease. Bull Amer Nat Hist 1979; 163:article 3.

9. Dias E, Pellegrino J. Alguns ensaios com o "Gamexanne" no combate aos transmissores da doenca de Chagas. Brasil Medico 1948; 62:185-190

10. Busvine J, Barnes M. Observations on mortality among insects exposed to dry insecticidal films. Bull Ent Res 1947; 38:81-90.

11. Perlowagora-Szumlewicz A. A eficácia do expurgo domiciliário com dieldrin no controle do vetor da doença de Chagas. Rev Bras Malar D Trop 1956; 8:289-304.

12. Shenone H, Zomosa E, Villarroel F, Rojas A, Alfaro E, Queiroz M. Acción de 7 formulaciones de insecticidas sobre Triatoma infestans criados em laboratório. Biol Chileno Parasit 1972; 27:14-22.

13. Pinchin R, Fanara DM, Oliveira Filho AM. A village scale trail of Pirimiphos-methyl (OMS 1424), wettable power and slow-release formulations, in comparison with $\mathrm{HCH}$ for he controle of Triatoma infestans in Brazil. World Health Organ 1984; VBC/82.840. 8 p. 
14. Sherlock I, Muniz TM. Combate ao Panstrongylus megistus com o malathion concentrado. Rev Soc Bras Med Trop 1975; 9:289-296.

15. Sherlock I, Muniz TM, Guitton N. A ação do malathion sobre os ovos de triatomíneos vetores de doença de Chagas. Rev Soc Bras Med Trop 1976; 10:77-84.

16. Fox I, Bayona Ig, Orozco HI. The toxicity of DDT, Dieldrin, Malathion and Fenthion to Rhodnius prolixus in laboratory. Bull World Health Organ 1966; 35:974-976.

17. Santos MAT, Areas MA, Reyes FGR. Piretróides: uma visão geral. Alim Nutr 2007; 18:339-349.

18. Dias JCP, Jemmio A. Sobre uma pintura inseticida para o controle de Triatoma infestans na Bolivia. Rev Soc Bras Med Trop 2008; 41:79-81.

19. Maloney KM, Ancca-Juarez J, Salazar R, Borrini-Mayori K, Niemierko M, Yukich JO, et al. Comparison of insecticidal paint and deltamethrin against Triatoma infestans (Hemiptera: Reduviidae) feeding and mortality in simulated natural conditions. J Vect Ecol 2013; 38:6-11.

20. Diotaiuti L, Penido CM, Araujo HS, Schofield CJ, Pinto CT. Excito-repellency effect of Deltamethrin on Triatomines under laboratory conditions. Rev Soc Bras Med Trop 2000; 33:247-252.

21. Herber O, Kroeger A. Pyretroid-impregnated curtains for Chaga's disease control in Venezuela. Acta Tropica 2003; 88:33-38.

22. Levy MZ, Quispe-Machaca VR, Ylla-VElasquez JL, Lance AW, Richards JM, Tath B, et al. Impregnated netting slows infestation by Triatoma infestans. Am J Trop Med Hyg 2008; 79:528-534.

23. Wood E, Licastro SA, Casabe N, Picollo MI, Alzogaray R, Zerba EN. A new tactic for Triatoma infestans control: fabrics impregnated with beta-cypermethrin. Rev Panam Salud Publica 1999; 6:1-7.

24. Dias JCP, Machado EMM, Borges EC, Moreira EF, Gontijo C, Azeredo BVM. Doença de Chagas em Lassance, MG. Reavaliação Clínico - epidemiológica 90 anos após a descoberta de Carlos Chagas. Rev Soc Bras Med Trop 2002; 35:167-176.

25. Pessoa GCD. Monitoramento da suscetibilidade ao piretróide deltametrina em populações de Triatoma sordida Stål, 1859 (Hemiptera: Reduviidae). 2008. 95 p. (Master's Dissertation). Centro de Pesquisas René Rachou da Fundação Oswaldo Cruz; 2008. Belo Horizonte.

26. Carvajal G, Mouganbure-Cueto G, Toloza AC. Toxicity of nonpyrethroid insecticides against Triatoma infestans (Hemiptera: Reduviidae). Mem Inst Oswaldo Cruz 2012; 107:675-679.

27. Depickère S, Buitrago R, Siñani E, Baune M, Monje M, Lopez $\mathrm{R}$, et al. Susceptibility and resistance to deltamethrin of wild and domestic populations of Triatoma infestans (Reduviidae: Triatominae) in Bolivia: new discoveries. Mem Inst Oswaldo Cruz 2012; 107:1042-1047.

28. Pessoa GCA. Perfil da suscetibilidade a deltametrina em populações de Triatoma sordida (Hemiptera: Reduviidae) do Estado de Minas Gerais procedentes de áreas com infestação persistente. 2012. 179 p. (Doctor's Thesis). Universidade Federal de Minas Gerais; 2012. Belo Horizonte.

29. Germano M, Picollo MI, Spillmann C, Mougabure-Cueto G. Fenithrothion: an alternative insecticide for the control of deltamethrin-resistant populations of Triatoma infestans in northern Argentina. Med Vet Entomol 2014; 28:21-25.

30. Gomez MB, Pessoa GCD, Orellana ALG, Cortez MR, Rosa ACL, Noireau F, et al. Susceptibility to deltamethrin of wild and domestic populations of Triatoma infestans of the Gran Chaco and the InterAndean Valleys of Bolivia. Parasit Vectors 2014; 7:497-503.

31. Pessoa GCD, Dias LS, Diotaiuti L. Deltamethrin pyrethroid susceptibility characterization of Triatoma sordida Stal, 1859
(Hemiptera: Reduviidae) populations in the Northern Region of Minas Gerais, Brazil. Rev Soc Bras Med Trop 2014; 47:426-429.

32. Pessoa GCD, Pinheiro LC, Ferraz ML, Mello BV, Diotaiuti L. Standartization of laboratory bioassays for the study of Triatoma sordida susceptibility to pyrethroid insecticides. Parasit Vectors 2015; 8:109.

33. Pessoa GCD, Trevizani NAB, Dias LS, Melo BV, Diotaiuti L. Toxicological profile of deltamethrin in Triatoma brasiliensis (Hemiptera: Reduviidae) in State of Ceará, Northeastern Brazil. Rev Soc Bras Med Trop 2015; 48:39-43.

34. Pessoa GCD, Rosa ACL, Bedin C, Wilhelms T, Mello F, Coutinho HS, et al. Susceptibility characterization of residual Brazilian populations of Triatoma infestans Klug, 1834 (Hemiptera: Reduviidae) to deltamethrin pyrethroid. Rev Soc Bras Med Trop 2015; 48:157-161.

35. Zerba EM, Wallace G, Picollo MI, Casabe N, Licastro S, Wood E, et al. Evaluación de la ß-cipermetrina para el control de Triatoma infestans. Pan Am J Public Health 1997; 1:133-137.

36. Vassena CV, Picollo MI, Zerba EN. Insecticida resistance in Brazilian Triatoma infestans and Venezuelan Rhodnius prolixus. Med Vet Entomol 2000; 14:51-55.

37. Vanessa CV, PicolIo MI. Monitoreo de resistencia a insecticidas en poblaciones de campo de Triatoma infestans y Rhodnius prolixus, insectos vectores de la efermedad de Chagas. (Internet). Rev Toxicologia en Linea (RETEL) 2003. 21 p. (Acessed 2007 May 12). Available at: http://www.sertox.com.ar/retel/n03/004.pdf

38. González-Audino P, Vassena C, Barrios S, Zerba EN, Picollo MI. Role of enhanced detoxication in a deltamethrin-resistant Population of Triatoma infestans (Hemiptera, Reduviidae) from Argentina. Mem Inst Oswaldo Cruz 2004; 99: 335-339.

39. Yon FC, Balta R, Garcia N, Troyes A, Cumpa H, Valdivia A. Susceptibilidad y resistência de Triatoma infestans y Panstrongylus herreri a lós insecticidas piretroides, Peru 2001. Rev Peru Med Exp Salud Publica 2004; 21:179-182.

40. Picollo MI, Vassena C, Orihuela PS, Barrios S, Zaidemberg M, Zerba E. High resistence to pyrethroid insecticides associated with ineffective field treatments in Triatoma infestans (Hemipetra: Reduviidade from Northern Argentina. J Med Entomol 2005; 42:637-642.

41. Sfara V, Zerba EM, Alzogaray RA. Toxicity of pyrethroids and repellency of diethyltoluamide in two deltamethrin-resitant colonies of Triatoma infestans Klug, 1834 (Hemiptera: Reduviidae). Mem Inst Oswaldo Cruz 2006; 101:89-94.

42. Reyes M, Angulo VM, Sandoval CM. Efecto tóxico de betacipermetrina, deltametrina y fenitrotión en cepas de Triatoma dimidiata (Latreille, 1811) y Triatoma maculata (Erichson, 1848) (Hemiptera, Reduviidae). Biomédica 2007; 27 (suppl I):75-82.

43. Santo-Orihuela PL, Vassena CV, Zerba EN, Picollo MI. Relative Contribution of Monooxygenase and Esterase to Pyrethroid Resistance in Triatoma infestans (Hemiptera: Reduviidae) from Argentina and Bolivia. J Med Entomol 2008; 45: 298-306.

44. Toloza AC, Germano M, Cueto GM, Vassena C, Zerba E, Picollo MI. Differencial patterns of insecticide resistance in eggs and first instar of Triatoma infestans (Hemiptera: Reduviidae) from Argentina and Bolivia. J Med Entomol 2008; 45:421-426.

45. Sonoda IV, Pessoa GCD, Cortez MR, Dias JC, Romanha AJ, Diotaiuti L. Susceptibility of Triatoma infestans to deltamethrin in Rio Grande do Sul, Brazil. Mem Inst Oswaldo Cruz 2009; 104:668-670.

46. Germano MD, Vassena CV, Picollo MI. Autosomal inheritance of deltamethrin resistance in field populations of Triatoma infestans (Heteroptera: Reduviidae) from Argentina. Pest Manag Sci 2010; 66:705-708. 
47. Germano MD, Acevedo GR, Mougabure Cueto GA, Toloza AC, Vassena CV, Picollo MI. New findings of insecticide resistance in Triatoma infestans (Heteroptera: Reduviidae) from the Gran Chaco. J Med Entomol 2010; 47:1077-1081.

48. Lardeux F, Depickère $\mathrm{S}$, Cuchon $\mathrm{S}$, Chaves T. Insecticide resistance of Triatoma infestans (Hemiptera, Reduviidae) vector of Chagas disease in Bolivia. Trop Med Int Health 2010; 15:1037-1048.

49. Obara TM. Caracterização da resistência a inseticidas em populações da subfamília Triatominae (Hemiptera: Reduviidae), vetores de Trypanosoma cruzi Chagas, 1909. 2010. 246 p. (Doctors Thesis). Centro Universidade de São Paulo; 2010; São Paulo.

50. Sonoda IV, Dias LS, Bezerra CM, Romanha AJ, Diotaiuti L. Susceptibility of Triatoma brasiliensis from State of Ceará, Northeastern Brazil, to the pyrethroid deltamethrin. Mem Inst Oswaldo Cruz 2010; 105:348-352.

51. Obara MT, Otreta VCG, Gurgel RG, Santos JP, Santalucia M, Rosa JA, et al. Monitoring the susceptibility of Triatoma sordida Stal, 1859 (Hemiptera: Reduviidae) to deltamethrin insecticide, in Central-Western Brazil. Rev Soc Bras Med Trop 2011; 44:206-212.

52. Roca-Acevedo G, Mougabure Cueto GA, Germano M, Orihuela PS, Cortez MR, Noireau F, et al. Susceptibility of sylvatic Triatoma infestans from Andeans Valleys of Bolivia a deltamethrin and fipronil. J Med Entomol 2011; 48:830-835.

53. Fabro J, Sterkel M, Capriotti N, Mougabure-Cueto G, Germano $\mathrm{M}$, Rivera-Pomar R, et al. Identification of a point of mutation associated with pyrethroid resistance in the para-type sodium channel of Triatoma infestans, a vector of Chagas disease. Infect Genet Evol 2012; 12:487-491.

54. Germano MD, Santo-Orihuela P, Roca-Acevedo G, Toloza AC, Vassena C, Picollo MI, et al. Scientific evidence of three different insecticide-resistant profiles in Triatoma infestans (Hemiptera: Reduviidae) populations from Argentina and Bolivia. J Med Entomol 2012; 49:1355-1360.

55. Germano MD, Picollo MI, Mouganbure-Cueto GS. Microgeographical study of insecticide resistance in Triatoma infestans from Argentina. Acta Tropica 2013; 128:561-565.

56. Roca-Acevedo G, Piollo MI, Santo-Orihuela. Expression of insecticide resistance in immature life stages of Triatoma infestans (Hemiptera: Reduviidae). J Med Entomol 2013; 50:816-818.

57. Santo-Orihuela PL, Carvajal G, Picollo MI, Vassena CV. Analysing deltamethrin susceptibility and pyrethroid esterase activity variations in sylvatic and domestic Triatoma infestans at the embryonic stage. Mem Inst Oswaldo Cruz 2013; 108:1031-1036.

58. Brow AQ, Paul R. Insecticide resistance in arthopods. WHO Monogr Geneva Ser 38. Geneva: World Health Organization; 1971.

59. Tabashink BE, Roush RT. Introduction. In: Roush RT, Tabashnik BE, editors. Pesticide resistance in arthropods. New York: Chapman and Hall; 1990. p. 1-3.

60. Germano MD, Picollo MI. Reproductive and developmental costs of deltamethrin resistance in Chagas disease vector Triatoma infestans. J Vector Ecol 2015; 40:1-7.

61. Bermudéz H, Valderrama F, Torrico F. Identification of sylvatic foci of Triatoma infestans in Central Bolívia. Am J Trop Med Hyg 1993; 49:371-375.

62. Panzera F, Ferrandis I, Callero L, Lucero C, Ferreiro MJ, Panzera Y, et al. Aportes recientes de lacitogenetica al estúdio de lós vectores de la enfermedad de Chagas. In: Arias AR, Maldonado M, editors. Taller Del Cono Sur, actualización de la Tripanosomiasis Americana. Paraguay; 2007. p.233.

63. Brogdon WG, Mcallister JC. Insecticide resistance and vector control. Emerg Infec Diseases 1998; 4:605-613.

64. Mouganbure Cueto G, Zerba E, Picollo MI. Biological effect of 1-dodecanol in teneral and post-teneral Rhodnius prolixus and Triatoma infestans (Hemiptera: Reduviidae). Mem Inst Oswaldo Cruz 2005; 100:59-61.

65. Pedrini N, Mijailovsky SJ, Girotti JR, Stariolo R, Cardozo RM, Gentile A, et al. Control of Pyrethroid-Resistant Chagas disease vectors with entomopathogenic fungi. PLoS Negl Trop Dis 2009; 3:1-11.

66. Yadav AD, Singh PK, Shrivastava VK. Pyrethroid resistance in Chagas disease vectors: The case of Triatoma infestans cuticle. Review. Indian J Entomol 2010; 68:213-216.

67. Saavedra-Rodriguez K, Suarez AF, Salas IF, Strode C, Ranson $\mathrm{H}$, Hemingway J, et al. Transcription of detoxification genes after permethrin selection in the mosquito Aedes aegypti. Insect Mol 2011; 21:61-77.

68. Capriotti N, Mougabure-Cueto G, Rivera-Pomar R, Ons S. L925I Mutation in the Para-type soddium channel is associated with pyrethroid resistance in Triatoma infestans from the Gran Chaco Region. PLoS Neg1 Trop Dis 2014; 8:e2659.

69. World Health Organization. Taller sobre la evaluación de efecto insecticida sobre triatominos. In: Workshop on the insecticide effect evaluation in Triatomines. Buenos Aires, Argentina. Acta Toxicol Argentina 1994; 2:29-33.

70. Milani R. Comportamento mendeliano de la resistenza alta azione abbattante del DDT: correlazione abbattimento e mortalid in Musca domestica. L Riv Parasitol 1954; 15:513-542.

71. World Health Organization (WHO). Criteria and meaningu of testes for determining the susceptibility or resistance of insecticides. VBC/81.6. WHO; 1981. 6p.

72. Amelotti I, Catalá S, Gorla DE. Experimental evaluation of insecticidal paints against Triatoma infestans (Hemiptera: Reduviidae), under natural climatic conditions. Parasit Vectors 2009; 2:30.

73. Zerba EN, Picollo MI. Resistencia a insecticidas piretroides en Triatoma infestans. Buenos Aires, Argentina: Centro de Investigaciones de Plagas e Insecticidas (CIPEIN) CITEFACONICET; 2002.

74. Panamerican Organization of Health (PAHO). II Reunion técnica latinoamericana de monitoreo de resistencia a insecticidas en triatominos vectores de Chagas. Panamá: PAHO; 11 al 13 de abril de 2005.20 p.

75. Diotaiuti L, Azeredo BVM, Busek SCU, Fernandes AJ. Controle do Triatoma sordida no Peridomicílio Rural do Município de Porteirinha, Minas Gerais, Brasil. Rev Pan Salud Publica 1998; 3:21-25.

76. Ministério da Saúde. I Seminário sobre técnicas e ferramentas de controle de doenças transmitidas por vetores. Brasília: Superintendência de Vigilância em Saúde; 2003.

77. Ministério da Saúde. II Seminário internacional sobre técnicas e ferramentas de controle de doenças transmitidas por vetores - recomendações. Brasília: Superintendência de Vigilância em Saúde; 2006. 